\title{
Carbon dioxide variations in the upper troposphere and lower stratosphere from GOSAT TANSO-FTS TIR profile data
}

\author{
Akihiro Honda ${ }^{1}$, Nawo Eguchi ${ }^{2}$, and Naoko Saitoh ${ }^{3}$ \\ ${ }^{1}$ Interdisciplinary Graduate School of Engineering and Sciences, Kyushu University, Kasuga Park 6-1, Kasuga, Fukuoka, \\ Japan; now at Mitsubishi Heavy Industries Ltd. \\ ${ }^{2}$ Research Institute for Applied Mechanics (RIAM), Kyushu University, Kasuga Park 6-1, Kasuga, Fukuoka, Japan \\ ${ }^{3}$ Center for Environmental Remote Sensing, Chiba University, Yayoi-cho 1-33, Inage-ku, Chiba, Japan
}

Correspondence: Nawo Eguchi (nawo@ riam.kyushu-u.ac.jp)

\begin{abstract}
Carbon dioxide $\left(\mathrm{CO}_{2}\right)$ variations in the upper troposphere and lower stratosphere (UT and LS; pressure $=300-$ $70 \mathrm{hPa}$ ) were investigated with profile data derived from the thermal infrared region (Band 4: 5.5-14.3 $\mu \mathrm{m}$ ) of the Thermal And Near-infrared Sensor for carbon Observation (TANSO)-Fourier Transform Spectrometer (FTS) onboard the Greenhouse gas Observing SATellite (GOSAT). The vertical profile data (Level 2; version 1) of $\mathrm{CO}_{2}$ mixing ratios were obtained by bias correction using the in situ aircraft data. Data with sufficient sensitivity were used for the analysis by selecting values with higher degrees of freedom. The analysis period is over four years from January 2010 to December 2013.

The increase of $\mathrm{CO}_{2}$ mixing ratios obtained with the bias correction in the UT and LS was 1.8-2.4 ppmv year ${ }^{-1}$ from 2010-2013, which is consistent with a previous observational study and almost the same as for the lower troposphere (LT). The seasonal variations in the UT and LS show that a maximum peak exists one or two months after the peak in the LT, and has an amplitude of 4-5 ppmv, which is less than that in the LT. The inter-annual variations observed in the tropical UT appear to be affected by ENSO events; higher (lower) $\mathrm{CO}_{2}$ mixing ratios were observed during La Niña (normal/El Niño) periods. Intra-seasonal variations over the Asian summer monsoon region were associated with both vertical and horizontal motions owing to deep convection and monsoonal anticyclonic circulation, respectively.
\end{abstract}

\section{Introduction}

The Intergovernmental Panel on Climate Change (IPCC) concluded that the main cause of global warming since the middle twentieth century is highly likely to be human activity (IPCC, 2013, 2021). Carbon dioxide $\left(\mathrm{CO}_{2}\right)$ is the major anthropogenic greenhouse gas causing this warming, and it has been reported that the mixing ratios of $\mathrm{CO}_{2}$ in the troposphere has risen from 280 to 400 parts per million volume (ppmv) in the past 170 years. The $\mathrm{CO}_{2}$ mixing ratios in 2018 and 2019 were 407.8 and 410.5 ppmv, respectively (WMO Greenhouse Gas Bulletin, 2019, 2020), and an annual record was set in 2020 of 413.2 ppmv (WMO Greenhouse Gas Bulletin, 2021), which was expected despite the reduction in economic activity due to COVID-19. It has been reported that the stratosphere is cooling (IPCC, 2013, 2021), which could be caused by increasing $\mathrm{CO}_{2}$ mixing ratios in the stratosphere in addition to a decrease in stratospheric ozone (cf. Langesmatz et al., 2003; Ramaswamy et al., 2006), because $\mathrm{CO}_{2}$ warms the troposphere and cools the stratosphere (Wang et al., 2020). Apart from $\mathrm{CO}_{2}$ production due 
to methane oxidation in the stratosphere, which is up to 1 ppmv (Boucher et al., 2009), there is no source of $\mathrm{CO}_{2}$ above the stratosphere other than the troposphere. It is clear that the increase in the stratospheric $\mathrm{CO}_{2}$ content is caused by $\mathrm{CO}_{2}$ being derived from the troposphere.

The rise in $\mathrm{CO}_{2}$ amount in the stratosphere is contributing to climate change (e.g., by providing suitable conditions for ozone depletion), and therefore warrants further investigation. $\mathrm{CO}_{2}$ is a long-lived gas and it is often assumed to have a constant mixing ratio in general climate models because it is generally thought to be well-mixed in the atmosphere. However, observations have revealed that the spatial and temporal distributions of $\mathrm{CO}_{2}$ mixing ratios are variable (e.g., Sawa et al., 2008), thus monitoring the global amount of $\mathrm{CO}_{2}$, including in the stratosphere, is essential for robust climate change predictions. The stratospheric $\mathrm{CO}_{2}$ amount on a global scale and exchange processes between the upper troposphere and lower stratosphere (UT and LS; 300-70 hPa) are not well understood. Therefore, the details of inflow of $\mathrm{CO}_{2}$ from the UT to LS remain unclear.

Aircraft and ground-based balloon observations have obtained in situ measurements of greenhouse gases in the UT and stratosphere (e.g., Nakazawa et al., 1995; Aoki et al. , 2003; Sawa et al., 2008; Umezawa et al., 2018). These previous studies were based on in situ observations with high accuracy, and found year-to-year variations, increases, and seasonal variations in $\mathrm{CO}_{2}$ mixing ratios in the UT-LS region. However, the spatial resolution and frequency of these in situ observations are limited. For example, the horizontal and vertical regions were limited to aircraft routes and pressure levels (i.e., mainly the UT-LS), and the ground-based observations have limited spatial coverage and temporal resolution. Furthermore, the intra-seasonal variation of $\mathrm{CO}_{2}$ in the UT-LS has not yet been investigated. Therefore, in order to understand the effect of stratospheric $\mathrm{CO}_{2}$ on climate change, it is necessary to determine the $\mathrm{CO}_{2}$ variations in the UT-LS region on a global scale.

Stratosphere-troposphere exchange (STE) normally occurs over the tropical regions, especially the western Pacific (i.e., the stratospheric fountain; (e.g., Newell and Gould-Stewart , 1981; Holton et al., 1995)) in the boreal winter, and the monsoon region in the boreal summer in Asia and North America (e.g., Gettelman et al., 2004; Santee et al., 2017; Yu et al., 2020). The intrusion process in the tropics is closely related to the strength of the Brewer-Dobson circulation (BDC), which is the general meridional circulation in the stratosphere driven by planetary waves propagated from the troposphere (Andrews et al., 1987). The BDC is stronger in the boreal winter than in the austral winter, which means the intrusion process has a seasonal cycle (e.g., Mote et al., 1996). In addition to the strength of the BDC, there are perturbations originating from the troposphere on hourly to interannual timescales, related to waves, convection, and radiation. For example, overshooting convective clouds cause tropospheric air to intrude directly into the stratosphere (e.g., Eguchi et al., 2016). Over the summer monsoon region, the stratosphere-troposphere exchange process is active due to the active convection and related wind fields (i.e., the Tibetan anticyclonic circulation) on intra-seasonal scales (e.g., Randel and Park, 2006). Over these areas, there are less in situ observations of the UT-LS region, and there are prominent intra-seasonal phenomena that characterize the area, such as the Madden-Julian Oscillation (MJO) (30 - 60 days) (Madden and Juluan, 1994) and the boreal summer intra-seasonal oscillation (10 - 90 days) (e.g., Kang et al., 1999; Annamalai and Slingo, 2001).

The $\mathrm{CO}_{2}$ mixing ratios obtained from space-born measurements were determined by the SCanning Imaging Absorption spectroMeter for Atmospheric CHartographY (SCIAMACHY) (Buchwitz et al., 2007), the Atmospheric Chemistry ExperimentFourier Transform Spectrometer (ACE-FTS) (Foucher et al., 2011), The Tropospheric Emission Spectrometer (TES) (Kulawik et al., 
2010), The Atmospheric Infrared Sounder (AIRS) (Maddy et al., 2008), and the Infrared Atmospheric Sounding Interferometer (IASI) (Crevoisier et al., 2009). However, the $\mathrm{CO}_{2}$ data from these satellite measurements are insufficient to investigate the $\mathrm{CO}_{2}$ variations in the UTLS, particularly on intra-seasonal timescales. The Greenhouse gas Observing SATellite (GOSAT) was launched in January 2009 to dedicated to observations of the mixing ratios of greenhouse gases such as $\mathrm{CO}_{2}, \mathrm{CH}_{4}$, and $\mathrm{H}_{2} \mathrm{O}$ on a global scale (Yokota et al., 2009). The Thermal And Near-infrared Sensor for the carbon Observation-Fourier Transform Spectrometer (TANSO-FTS) instrument (e.g., Kuze et al., 2016) onboard GOSAT measures the greenhouse gas mixing ratios from the surface to the LS using the thermal infrared band. GOSAT observes every three days over almost the entire region from $80^{\circ} \mathrm{N}$ to $80^{\circ} \mathrm{S}$ in a polar orbit with a $100 \mathrm{~min}$ cycle. Ground-based and aircraft instruments made 248 observations in September 2019 (WMO WDCGG Data Summary, 2020), but about 80,000 observations of the same quality, both with and without cloud cover, are made by GOSAT each month. This enables data to be acquired for areas that cannot be studied by ground-based observations.

GOSAT has been observing from June 2009 to the present day and GOSAT-2, which was launched on 29 October 2018, also monitors greenhouse gases from space. It is now possible to determine the three-dimensional distribution of greenhouse gases, and also intra-seasonal (30-60 days), seasonal, and inter-annual (a few years) variations since June 2009. These data are useful for numerical models and improving the accuracy of emission measurements. For example, the total column $\mathrm{CO}_{2}$ mole fraction $\left(\mathrm{XCO}_{2}\right)$ data derived from shortwave infrared (SWIR) GOSAT observations are used for estimating the surface flux with an atmospheric transport model (e.g., Maksyutov et al., 2021; Patra et al., 2021; Houweling et al., 2015; Takagi et al., 2011).

Numerous previous studies have been conducted on the total atmospheric column $\mathrm{CO}_{2}$ mole fraction in the middle (MT) and lower (LT) troposphere using satellite observations. The seasonal variations were investigated by Yoshida et al. (2013); Lindqvist et al. (2015). Ying et al. (2019) determined inter-annual and seasonal variations of $\mathrm{CO}_{2}$ from GOSAT and the AIRS onboard the Aqua satellite, and Jiang et al. (2010) measured $\mathrm{MT} \mathrm{CO}_{2}$ variations using the AIRS. However, there have been fewer studies of $\mathrm{CO}_{2}$ variations in the UT-LS on a global-scale by satellite measurements. Diallo et al. (2017) investigated variations in $\mathrm{CO}_{2}$ in the UT and stratosphere using a Lagrangian backward trajectory model driven by ERA-Interim reanalysis meteorology and tropospheric $\mathrm{CO}_{2}$ measurements.

In this study, we investigated $\mathrm{CO}_{2}$ mixing ratios in the UT-LS region on a global scale at several temporal scales, from intraseasonal, seasonal, to inter-annual, using GOSAT profile data after corrections for data bias and quality. Section 2 describes the $\mathrm{CO}_{2}$ profile data derived from the thermal infrared band of the GOSAT TANSO-FTS, and the bias correction and analytical methods, including the definition of the temporal variations. Section 3 presents the $\mathrm{CO}_{2}$ trend from 2010-2013, and seasonal, inter-annual, and intra-seasonal variations in the UT-LS. Finally, Section 4 summarises our results and conclusions.

\section{Data and methodology}

\subsection{GOSAT observation overview and spectral information}

90 The GOSAT satellite consists of two sensors: The TANSO-FTS and the TANSO-Cloud and Aerosol Imager (TANSO-CAI). Bands 1, 2, and 3 of the TANSO-FTS sensor observed the short infrared wavelength (SWIR), with wavelengths of 0.76, 1.6, 
and $2.0 \mu \mathrm{m}$, respectively, which are the spectra of solar radiation reflected from the ground surface (e.g., Kuze et al., 2012, 2016; Yoshida et al., 2011). From the SWIR band, the column-average mole fractions $\left(\mathrm{XCO}_{2}, \mathrm{XCH}_{4}\right.$, and $\left.\mathrm{XH}_{2} \mathrm{O}\right)$ of $\mathrm{CO}_{2}$, $\mathrm{CH}_{4}$, and $\mathrm{H}_{2} \mathrm{O}$ can be retrieved (Yoshida et al., 2011, 2013). Band 4 of the TANSO-FTS is the TIR band, and observes the infrared spectrum $(5.5-14.3 \mu \mathrm{m})$ of Earth's radiation emitted from the atmosphere and the surface. From the TIR band, the vertical mixing ratio distributions of $\mathrm{CO}_{2}$ and $\mathrm{CH}_{4}$ can be retrieved (Saitoh et al., 2009, 2016). Given that the resolution of the spectra is $0.2 \mathrm{~cm}^{-1}$ higher than that of conventional satellite equipment, except for band 1, the atmospheric mixing ratio data are of high accuracy. For example, the accuracy is about 4 ppmv for $\mathrm{XCO}_{2}$ (Yoshida et al., 2011). Moreover, the high-resolution spectra allow high-resolution vertical data to be obtained by TIR.

The TANSO-CAI sensor observes clouds, aerosols, and surface conditions during the day. From the TANSO-CAI observational data, it can be determined whether there is cloud over a wide range, including the field of view (instant field of view, IFOV, which is approximately $10.5 \mathrm{~km}$ in diameter) of the TANSO-FTS sensor (Ishida and Nakajima, 2009; Ishida et al., 2011). If there is an aerosol or a cloud within the IFOV, then the retrieval processing of $\mathrm{CO}_{2}, \mathrm{CH}_{4}$, and $\mathrm{H}_{2} \mathrm{O}$ mixing ratios is not conducted on the SWIR and TIR spectra. However, optically thinner clouds are not detected by the TANSO-CAI; therefore, the accuracy of the TIR profile data has a bias with respect to cloud frequency, especially for thinner cloud.

This study used Level 2 vertical profile data (version 1; latest version) retrieved from the GOSAT TIR spectrum acquired over the clear sky for both day and night for four years from 1 January 2010 to 31 December 2013. The retrieval process for the vertical mixing ratio distribution of $\mathrm{CO}_{2}$ is explained in detail in Saitoh et al. $(2009,2016)$. The pressure levels are 28 layers from the surface to $0.1 \mathrm{hPa}$. The present study defined the UT-LS region as $287.30-90.85 \mathrm{hPa}$, and the number of retrieved layers is 9 to 14 in Table 1 of Saitoh et al. (2016). The $\mathrm{CO}_{2}$ mixing ratios data were averaged in a $5^{\circ}$ box for the longitude and latitude. The algorithm was described in detail by Saitoh et al. (2016), and the altitude distribution data for 28 layers were specifically derived. The algorithm has a sensitivity peak in the upper troposphere.

\subsection{Bias correction and data pre-processing}

Saitoh et al. (2016) determined the TIR $\mathrm{CO}_{2}$ profile in the UT-LS region using Continuous Measurement Equipment (CME) observations of the Comprehensive Observation Network for TRace gases by AIrLiner (CONTRAIL) (Machida et al., 2008), and the accuracy of the $\mathrm{CO}_{2}$ measurements was less than $0.2 \mathrm{ppmv}$ (Machida et al., 2008, 2011). It was found that the $\mathrm{CO}_{2}$ mixing ratios in the UT-LS had a maximum bias of $2.3 \mathrm{ppmv}$ between the equator and $40^{\circ} \mathrm{N}$ in the boreal summer and $2.4 \mathrm{ppmv}$ between $20^{\circ} \mathrm{N}$ and $40^{\circ} \mathrm{N}$ in the boreal spring during the four years from 2010 to 2013. In summary, Saitoh et al. (2016) found

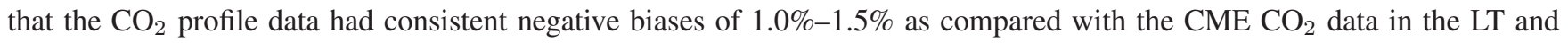
MT regions (736-287 hPa). Saitoh et al. (2017) found that the $\mathrm{CO}_{2}$ profile data at the $\mathrm{CME}$ altitude range (approximately 11 $\mathrm{km}$ ) was less than $0.5 \mathrm{ppmv}$ at lower latitudes and $1.0 \mathrm{ppmv}$ at middle and high latitudes. In addition, after applying the bias correction coefficient based on a comparison with CONTRAIL, both the trends and seasonal fluctuations showed good agreement with the Nonhydrostatic Icosahedral Atmospheric Model (NICAM)-Transport Model (TM) (Niwa et al., 2011, 2012) after inverse analysis. The present study conducted a bias correction at the retrieved layers (287.30-90.85 hPa) for each month 

Saitoh et al. $(2016,2017)$.

In addition, data with a higher degree of freedom (DOF), with more than two times the standard deviation from the average of each month, were used for the analysis, because we intended to use data that were not constrained by a priori information. Furthermore, anomalous data that were more than five times the standard deviation from the average of each month were not used for the analysis.

The trend was derived from the slope of a linear least-square fit defined by equation (1) from the monthly mean time-series of $\mathrm{CO}_{2}$ mixing ratios from January 2010 to December 2013.

$C O_{2 t}(t)=a t+b$

, where $a$ and $b$ are the slope and intercept, respectively. The trend was calculated at each pressure level and latitude at $5^{\circ}$ intervals. Because the unit of $a$ is ppmv month ${ }^{-1}$, the trend is $a$ multiplied by 12 months.

The seasonal cycle was derived from a harmonic analysis (Fourier time-series analysis), similar to Nakazawa et al. (1991), of the monthly mean time-series subtracted from the linear trend defined by equation (1). Seasonal cycle components were extracted from the observed time-series data:

$S(t)=\sum_{i=1}^{k}\left(A_{i} \sin 2 \pi i t+B_{i} \cos 2 \pi i t\right)$

140 , where $A_{i}$ and $B_{i}$ are the amplitude parameters of the sine and cosine terms, respectively. $t$ is the elapsed time since January 2010. $i$ is the order and $k$ was set to three, which satisfactorily expresses the sub-seasonal and annual cycles.

For analysis of the inter-annual $\mathrm{CO}_{2}$ variations, we used the anomaly data from the four-year monthly mean derived from equation (2), after subtracting the trend for each month and pressure and latitude.

Meteorological data, including the temperature and horizontal wind field, were obtained by ECMWF reanalysis version 5 (ERA5) ().

\section{Results}

\section{1 $\mathrm{CO}_{2}$ mixing ratio trends from 2010 to 2013}

Figure 1 shows the trend of $\mathrm{CO}_{2}$ mixing ratios at $250 \mathrm{hPa}$. The trend at $250 \mathrm{hPa}$ was obtained from bias-corrected data within the latitudinal range of $30^{\circ} \mathrm{S}-70^{\circ} \mathrm{N}$. The filled circles in Fig.1 show data from latitudes where the data were bias-corrected. The trend at $250 \mathrm{hPa}$ was around $2.0 \mathrm{ppmv}^{\text {year }}{ }^{-1}$.

Table 1 shows a summary of the trend at several pressure levels during the analysis period. The trend was $1.82-2.08$ ppmv year $^{-1}$ in the UT $(150$ and $250 \mathrm{hPa})$ and the LS (100 hPa), and $1.87 \mathrm{ppmv}^{-1} \mathrm{ar}^{-1}$ at $500 \mathrm{hPa}$. The trend in the Southern Hemisphere $\left(30^{\circ} \mathrm{S}-\right.$ Eq. $)$ was relatively larger than in the Northern Hemisphere (Eq. $\left.-30^{\circ} \mathrm{N}\right)$; the difference at $250 \mathrm{hPa}$ was 0.15 ppmv year ${ }^{-1}$. In particular, the trend was large over the Atlantic, Indian, and western Pacific oceans (not shown). These values 
are consistent with in situ observations, such as CONTRAIL, which obtained an increase of 1.8-2.0 ppmv/yr from 20052010 (Sawa et al., 2012). For example, the growth rate at Mauna Loa was 2.22 ppmv year $^{-1}$ during the analysis period (c.f. Thoning et al., 1989). The increase of 1.82-2.08 ppmv/yr in the UT-LS is similar to that near the surface (2.0-2.9 ppmv/yr) (WMO Greenhouse Gas Bulletin, 2012, 2013, 2014), and thus it appears that $\mathrm{CO}_{2}$ is well mixed from the LT to UT.

\subsection{Seasonal cycle}

Figure 2 shows a time-latitude cross-section of zonal mean and four-year averaged $\mathrm{CO}_{2}$ mixing ratios at each pressure level from January 2010 to December 2013. The four-year average values were derived from the de-trended time-series at each latitude and pressure.

At $500 \mathrm{hPa}$ (Fig.2d), a high $\mathrm{CO}_{2}$ mixing ratio appears at higher latitudes between $40^{\circ} \mathrm{N}$ and $65^{\circ} \mathrm{N}$ in March and April. Prior to that, $\mathrm{CO}_{2}$ mixing ratios increase from November. In the Northern Hemisphere, the peak month of the seasonal variation becomes later approaching the equator. At low latitudes in the Southern Hemisphere (around $30^{\circ} \mathrm{S}$ ), the peak is in September. The seasonal amplitude is approximately 8 ppmv at higher latitudes and this decreases at lower latitudes. The peak of the seasonal cycle around the equator is June. These features are similar to that at the near-surface, which reflects seasonal controls on vegetation in the Northern Hemisphere (e.g. Keeling et al., 1996).

At $250 \mathrm{hPa}$, the maximum $\mathrm{CO}_{2}$ mixing ratios occur in May at lower latitudes $\left(30^{\circ} \mathrm{S}\right.$ to $30^{\circ} \mathrm{N}$ ), which is one or two months earlier than at mid-latitudes at $500 \mathrm{hPa}$. The $\mathrm{CO}_{2}$ mixing ratio increases in January or February and decreases from June. The seasonal amplitude at lower latitudes is approximately 5 ppmv, which is smaller than at lower altitudes. Furthermore, the amplitude at higher latitudes (north of $30^{\circ} \mathrm{N}$ ) is smaller than that at lower latitudes.

At $150 \mathrm{hPa}$, there are two maximum $\mathrm{CO}_{2}$ mixing ratio peaks at $30^{\circ} \mathrm{N}$ from April to May and at $20^{\circ} \mathrm{S}$ from May to July. The southern peak at $20^{\circ} \mathrm{N}$ extends southward with each month. The northern peak at $30^{\circ} \mathrm{N}$ is independent of the southern peak and extends northward, but only until June. Similar to $250 \mathrm{hPa}$, the $\mathrm{CO}_{2}$ mixing ratios at lower latitudes were higher than those at higher latitudes.

At $100 \mathrm{hPa}$, the $\mathrm{CO}_{2}$ mixing ratio peak at $15^{\circ} \mathrm{N}$ occurred in May and June. The higher mixing ratio extended to the Southern Hemisphere across the equator, and it appears that this extension causes the seasonal cycle at lower latitudes in the Southern Hemisphere. The amplitude was approximately 4 ppmv. In summary, a seasonal $\mathrm{CO}_{2}$ cycle was observed in the UT, but the amplitude was small. The peak was located at the lower latitudes and occurred earlier than the peak at the lower altitudes (150 and $250 \mathrm{hPa}$ ).

Figure 3 shows the latitude and pressure sections of zonal and monthly averaged $\mathrm{CO}_{2}$ mixing ratios from 2010 to 2013 after de-trending. The pressure range is $735-30 \mathrm{hPa}$. Solid and dashed contours show negative and positive pressure vertical velocities $(-/+1.0 \mathrm{~Pa} / \mathrm{s})$ and dotted contours show the potential temperatures at $370 \mathrm{~K}$. The $370 \mathrm{~K}$ potential temperature defines the physical surface of the tropopause.

Seasonal variation is clearly evident at mid- and high latitudes in the Northern Hemisphere, especially below the MT (300 hPa). High mixing ratios of $\mathrm{CO}_{2}$ occur at mid- and high latitudes and extend from the south up to the equator between March and May. After June, the $\mathrm{CO}_{2}$ mixing ratios at mid- and high latitudes decreased until September, and then increased gradually 
from October to the following May. At lower latitudes, high $\mathrm{CO}_{2}$ mixing ratios from the LT to UT were observed from April to June, which are related to the location of upward motion in a Hadley cell in the Northern Hemisphere (Fig. 3).

There are high $\mathrm{CO}_{2}$ mixing ratios in the UT in the equatorial region, which is the Tropical Tropopause Layer (TTL); the pressure range is $150-70 \mathrm{hPa}$. This high $\mathrm{CO}_{2}$ mixing ratio region is isolated from the $\mathrm{MT}$ throughout the year, except for during March-June, when high $\mathrm{CO}_{2}$ mixing ratios extend from the LT to UT and lower latitudes (equator to $30^{\circ} \mathrm{N}$ ) due to upward vertical motion, such as Hadley cells. This feature is consistent with the seasonal cycle in the UT ( $250 \mathrm{hPa})$ shown in Figure 2c.

During the boreal winter (austral summer) season (December-February), the lowest mixing ratio was observed up to 200 $\mathrm{hPa}$ along the upward vertical velocity zone located to the south of the equator, which can reach a higher altitude than during the northern summer. During the boreal summer when the annual cycle of $\mathrm{CO}_{2}$ is at a minimum, the upward motion was active over the Asian and American monsoon regions $\left(15^{\circ} \mathrm{N}-45^{\circ} \mathrm{N}\right)$, where the $\mathrm{CO}_{2}$ mixing ratio gradually decreased in the MT and UT.

Given that the source of $\mathrm{CO}_{2}$, particularly anthropogenic $\mathrm{CO}_{2}$, is at lower altitudes at mid-latitudes in the Northern Hemisphere, the high $\mathrm{CO}_{2}$ mixing ratio is transported from mid-latitudes to lower latitudes in the LT by dynamical circulation, such as Ferrel and Hadley circulations. This suggests that the high $\mathrm{CO}_{2}$ mixing ratio is transported from lower altitudes during the boreal spring to early summer, and remains in the equatorial region where there are no anthropogenic sources or sink of $\mathrm{CO}_{2}$. Furthermore, the $\mathrm{CO}_{2}$ mixing ratios in the equatorial region of the UT reached a minimum around September, which means that the aforementioned transport from mid-latitudes to lower latitudes by general circulation, such as Ferrel and Hadley circulations, takes 1-2 months. In the LS above the tropopause at approximately $350 \mathrm{~K}$, the $\mathrm{CO}_{2}$ mixing ratio decreased gradually with increasing altitude. In the Northern Hemisphere, the $\mathrm{CO}_{2}$ mixing ratio vertical gradient varied with season. The gradient in the Southern Hemisphere was steeper than in the Northern Hemisphere and, for example, the $\mathrm{CO}_{2}$ mixing ratio decreased from $385 \mathrm{ppmv}$ at $250 \mathrm{hPa}$ to $370(375) \mathrm{ppmv}$ at $100 \mathrm{hPa}$ at $60^{\circ} \mathrm{S}\left(60^{\circ} \mathrm{N}\right)$ in January. This suggests that the $\mathrm{CO}_{2}$ mixing ratio in the UT and LS depends on vertical and horizontal transport in the troposphere.

\subsection{Year-to-year variation}

Figure 4 shows a time-latitude plot of $\mathrm{CO}_{2}$ mixing ratios at 100, 150, 250, and $500 \mathrm{hPa}$ from January 2010 to December 2013, using de-trended data at each latitude.

At $500 \mathrm{hPa}$, the seasonal variation at northern high latitudes $\left(50^{\circ} \mathrm{N}\right)$ is large, as shown in Fig. 2. The highest $\mathrm{CO}_{2}$ mixing ratio was observed in April at high latitudes and extended to lower latitudes in each year. In April 2013, this extension was larger than for the other years. Note that the bias correction was not applied to the data at high latitudes and, therefore, the bias remains at high latitudes. The minimum $\mathrm{CO}_{2}$ mixing ratios were located at latitudes higher than $60^{\circ} \mathrm{N}$ and at around $15^{\circ} \mathrm{N}$ from June to November. The southern minimum extended to the Southern Hemisphere from September to April. In 2011, the minimum $\mathrm{CO}_{2}$ mixing ratio near the equator was larger than for the other years.

At $250 \mathrm{hPa}$, the year-to-year variations appear to be larger than at other pressures. The $250 \mathrm{hPa}$ pressure level at lower latitudes is in the UT and, in general, corresponds to the maximum of zonal winds that are influenced by deep convection and 
general circulation. At mid- and high latitudes, the $250 \mathrm{hPa}$ pressure level is located in the LS. At lower latitudes $\left(30^{\circ} \mathrm{N} / \mathrm{S}\right)$, one peak of high $\mathrm{CO}_{2}$ mixing ratios was observed in 2010 and 2013, and two peaks were observed in 2011 and 2012. These peaks at lower latitudes reflect upward motion associated with deep convection and Hadley circulation. The years 2011 and 2012 were normal years in terms of ENSO and, therefore, the upward motion was weaker than in La Niña and El Niño years (e.g. Oort and Yienger, 1996; Yun et al., 2021). The high $\mathrm{CO}_{2}$ mixing ratios extended to higher latitudes in both hemispheres, however, the northern maximum extended further than the southern maximum from April to June.

At $150 \mathrm{hPa}$, two maximum $\mathrm{CO}_{2}$ mixing ratios were located at $35^{\circ} \mathrm{N}$ and the lower latitudes of $15^{\circ} \mathrm{N} / \mathrm{S}$. The southern maximum shows larger year-to-year variations than the northern maximum. The peak at $35^{\circ} \mathrm{N}$ occurred in April, which suggests that the high mixing ratio at $150 \mathrm{hPa}$ could have resulted from transport from the $\mathrm{LT}$ at mid-latitudes. The $150 \mathrm{hPa}$ pressure level corresponds to the base of the TTL at lower latitudes, and the deep convection zone in the tropics.

At $100 \mathrm{hPa}$, the higher mixing ratios are located at $15^{\circ} \mathrm{N}$ in May-June each year and extend to the Southern Hemisphere in June, and also the mid-latitudes in the Northern Hemisphere. The extension to higher latitudes was more prominent in the Northern Hemisphere than in the Southern Hemisphere. The $100 \mathrm{hPa}$ pressure level in the tropics is in the TTL (within $25^{\circ} \mathrm{N} / \mathrm{S}$ ), but is located in the LS in extratropical regions. This suggests that high $\mathrm{CO}_{2}$ mixing ratios gradually enter the $\mathrm{LS}$ at $100 \mathrm{hPa}$ during the boreal spring and early summer, and the seasonal cycle is then influenced by dynamic processes (i.e., vertical transport due to deep convection associated with monsoons), because $\mathrm{CO}_{2}$ is a long-lived species in the UT and stratosphere.

Figure 5 is similar to Figure 4, but the anomaly shown is the seasonal cycle at 150 and $500 \mathrm{hPa}$. In the tropics at $150 \mathrm{hPa}$ (Fig. 5(a)), positive anomalies occurred from April to February in 2010/2011 and from January to December in 2013. However, a negative anomaly occurred from June 2011 to December 2012. The positive (negative) anomalies correspond to La Niña (El Niño or normal) phases. The positive anomaly extended over the tropics, and the negative anomaly was located on both sides of the positive anomaly in the boreal summer of 2010.

The same features are evident at $250 \mathrm{hPa}$. The zonal averaged amplitude of the year-to-year variation was $\pm 1.25 \mathrm{ppmv}$ at 250 $\mathrm{hPa}$ at the equator, and the amplitude at $150 \mathrm{hPa}$ was slightly larger than that at $250 \mathrm{hPa}$. At $100 \mathrm{hPa}$, year-to-year variations were not clear, although weak variations were observed in the northern subtropics. The opposite features were observed in the tropics at 500hPa (Fig. 5(b)); the negative (positive) anomalies were in La Niña (El Niño or normal) phases, which is consistent with a previous study (e.g. Jiang et al., 2010).

Given that the zonal averaged vertical wind in the tropics was weaker during the La Niña period than in normal years and El Niño periods (not shown), it is possible that air with higher $\mathrm{CO}_{2}$ mixing ratios preferred to remain in the MT and, as a result, there was less air transport to the UT-LS during the La Niña period. This again shows that the $\mathrm{CO}_{2}$ mixing ratio in the UT-LS depends on the magnitude of upward motion.

\subsection{Intra-seasonal variation}

The Asian summer monsoon region is an important area of stratospheric and tropospheric (ST) exchange processes. In partic-

ular, the intra-seasonal variations over this region are active and reflect the seasonal effects of the Asian monsoon from June to September. Xiong et al. (2009) found that the strong transport of atmospheric pollutants from LT to UT in Asian during the 
monsoon season by AIRS $\mathrm{CH}_{4}$ observation. The intra-seasonal variations of trace gases have been investigated to understand ST processes (e.g. Park et al., 2007, 2008, 2009). Intra-seasonal variations in carbon monoxide (CO) as a tropospheric tracer and ozone and $\mathrm{HCN}$ as a stratospheric tracer both reflect the effects of vertical transport via deep convection and horizontal advection caused by anticyclones associated with the Asian monsoon.

The intra-seasonal variations of $\mathrm{CO}_{2}$ mixing ratios varied from year-to-year, especially during the boreal spring to autumn seasons. Figure 6 shows the time-latitude section of $\mathrm{CO}_{2}$ mixing ratios at $250 \mathrm{hPa}$ over the Asian summer monsoon region averaged between $60^{\circ} \mathrm{E}$ and $120^{\circ} \mathrm{E}$ from the equator to $45^{\circ} \mathrm{N}$ from 1 April to 31 October of each year. The data were de-trended and are a seven-day running average.

There are $\mathrm{CO}_{2}$ mixing ratio variations over durations of a few weeks in the UT, and high mixing ratios were observed from May to June, especially in May 2010 and May-June in 2013. Given that the high $\mathrm{CO}_{2}$ mixing ratios were transported from the LT by deep convection, as evident from the seasonal variation, it appears that the intra-seasonal variation was also related to deep convection. After June, the $\mathrm{CO}_{2}$ mixing ratios started to decrease gradually from high latitudes, except in August 2012.

Figure 7 shows a horizontal section of $\mathrm{CO}_{2}$ mixing ratios at $250 \mathrm{hPa}$ from 16 June to 1 September 2012, with 15-day intervals obtained from the 14-day mean. The high mixing ratios of $\mathrm{CO}_{2}$ were mainly located on the southwestern side of the Tibetan Plateau high (i.e., the Asian monsoon high) in June (Fig.7(a)). The high mixing ratio in the UT was caused by vertical transport due to deep convection associated with the Asian Monsoon. The maximum mixing ratio area moved northward of the Tibetan Plateau high in July when the Tibetan Plateau high extended to the east and strengthened (Fig.7(b,c)). At the same time, the $\mathrm{CO}_{2}$ mixing ratio on the eastern side of the study area decreased gradually. There is an east-west change in mixing ratio.

In August, the high-mixing ratio area (>393 ppmv) was diminished, and lower $\mathrm{CO}_{2}$ mixing ratios were transported horizontally from the northeastern part of the study area to lower latitudes along the Asian monsoon high. In September when the Tibetan Plateau high weakened, the $\mathrm{CO}_{2}$ mixing ratio recovered in the western part of the study area. $\mathrm{CO}_{2}$ mixing ratios on an intra-seasonal timescale are influenced by vertical transport due to deep convection and horizontal advection caused by horizontal wind fields in the UT.

\section{Summary and conclusions}

$\mathrm{CO}_{2}$ mixing ratio variations in the UT and LS were investigated with the GOSAT TANSO-FTS TIR Level 2 dataset (version 1) on intra-seasonal to inter-annual timescales. The data were bias-corrected based on Saitoh et al. $(2016,2017)$ and excluded smaller DOF values. The level 2 data were converted to a $5^{\circ} \mathrm{N}$ box grid and monthly mean values, except for the intra-seasonal analysis.

285 The increase of $\mathrm{CO}_{2}$ in the UT-LS was 1.8-2.4 ppmv year $^{-1}$, which is consistent with that obtained from in situ aircraftobtained data by CONTRIAL (e.g., Machida et al., 2008). The increase in the tropical Southern Hemisphere in the MT and UT ( 250 and $500 \mathrm{hPa}$ ) was slightly (approximately 0.5 ppmv year $^{-1}$ ) larger than that in the Northern Hemisphere.

In terms of the seasonal cycle, the maximum $\mathrm{CO}_{2}$ mixing ratio was in May-June in northern mid-latitudes, and one or two months later than in the LT and MT. This suggests that vertical transport and mixing between the LT and UT occurs on a 
timescale of one or two months. The amplitude of the seasonal cycle in the UT was $4-6$ ppmv, which is $\leq 50 \%$ of that in the LT and MT. This is due to the absolute mixing ratio decreasing with altitude and, to a lesser extent, mixing with a low $\mathrm{CO}_{2}$ mixing ratio air mass.

Inter-annual variations were clearly evident in the tropics, and appear to be affected by ENSO events. At $150 \mathrm{hPa}$, higher (lower) $\mathrm{CO}_{2}$ mixing ratios occurred during La Niña (normal/El Niño) periods. This suggests that the higher $\mathrm{CO}_{2}$ mixing ratios in the UT during the La Niña periods were induced by weaker vertical transport than during normal/El Niño periods.

In terms of intra-seasonal variations, $\mathrm{CO}_{2}$ mixing ratios over the Asian summer monsoon region were variable on a timescale of a few weeks, which reflect vertical and horizontal transport owing to deep convection and monsoonal anticyclonic circulation, respectively. Vertical transport increased the $\mathrm{CO}_{2}$ mixing ratios in the upper layer for short durations (a few days) over a relatively small area. Horizontal transport associated with the Tibetan Plateau anticyclone caused the $\mathrm{CO}_{2}$ mixing ratios to vary between the UT and LS on a sub-continental scale.

Data availability. The TANSO-FTS data are available via the GOSAT Data Archive Service (GDAS) at https://data2.gosat.nies.go.jp/. The ECMWF Reanalysis version 5 (ERA5) data (daily basis) were taken from https://www.ecmwf.int/en/forecasts/datasets/reanalysisdatasets/era5.

Author contributions. Eguchi designed the study and prepared the manuscript, and Honda and Eguchi analysed the data. Saitoh developed the $\mathrm{CO}_{2}$ profile data. All authors discussed the data and manuscript.

Competing interests. The authors declare that they have no conflicts of interest.

Acknowledgements. This study was undertaken within the framework of the GOSAT Research Announcement and conducted as a joint research program of CEReS, Chiba University (2019-2021). This research was partially supported by a Grant-in-Aid for the 2019-2021 Initiative for Realising Diversity in the Research Environment through the Diversity and Super Global Training Program for Female and Young Faculty (SENTAN-Q). 


\section{References}

Andrews, D. G., Holton, J. R., and Leovy, C. B: Middle Atmosphere Dynamics, International Geophysics Series vol. 40, Academic Press, San Diego, USA, 1987.

Annamalai, H., and Slingo J. M.: Active/break cycles: diagnosis of the intraseasonal variability of the Asian Summer Monsoon, Clim. Dyn., $18,85-102,2001$.

Aoki, S., Nakazawa, T., Machida, T., Sugawara, S., Morimoto, S., Hashida, G., Yamanouchi, T., Kawamura, K., and Honda, H.: Carbon dioxide variations in the stratosphere over Japan, Scandinavia and Antarctica, Tellus B, 55, 178-186, 2003.

Boucher, O., Friedlingstein, P., Collins, B., and Shine, K. P.: The indirect global warming potential and global temperature change potential due to methane oxidation, Environ. Res. Lett. 4 044007, http://dx.doi.org/10.1088/1748-9326/4/4/044007, 2009.

Buchwitz, M., Schneising, O., Burrows, J. P., Bovensmann, H., Reuter, M., and Notholt, J.: First direct observation of the atmospheric $\mathrm{CO}_{2}$ year-to-year increase from space, Atmos. Chem. Phys. 7, 4249-4256, 2007.

Crevoisier, C., Ch'edin, A., Matsueda, H., Machida, T., Armante, R., and Scott, N. A.: First year of upper tropospheric integrated content of $\mathrm{CO}_{2}$ from IASI hyperspectral infrared observations, Atmos. Chem. Phys., 9, 4797-?4810, https://doi.org/10.5194/acp-9-4797-2009, 2009.

Diallo, M., Legras, B., Ray, E., Engel, A, and Juan A. A.: Global distribution of $\mathrm{CO}_{2}$ in the upper troposphere and stratosphere, Atmos. Chem. Phys., 17, 3861-3878, 2017.

Eguchi, N., Koder, K., Funatsu, B. M., Takashima, H., and Ueyama, R.: Rapid convective transport of tropospheric air into the tropical lower stratosphere during the 2010 sudden stratospheric warming, SOLA, 12A, 13-17, doi:10.2151/sola.12A-003, 2016.

Foucher, P. Y., Chedin, A., Armante, R., Boone, C., Crevoisier, C., and Bernath, P.: Carbon dioxide atmospheric vertical profiles retrieved from space observation using ACE-FTS solar occultation instrument, Atmos. Chem. Phys., 11, 2455-?2470, doi:10.5194/acp-11-2455$2011,2011$.

Gettelman, A., Kinnison, D. E., Dunkerton, T. J., and Brasseur, G. P.: Impact of monsoon circulations on the upper troposphere and lower stratosphere, J. Geophys. Res., 109, D22101, doi:10.1029/2004JD004878, 2004.

Hersbach, H., Bell, B., Berrisford, P., Hirahara, S., Horanyi, A., Munoz-Sabater, J., Nicolas, J., Peubey, C., Radu, R., Schepers, D., Simmons, A., Soci, C., Abdalla, S., Abellan, X., Balsamo, G., Bechtold, P., Biavati, G., Bidlot, J., Bonavita, M., De Chiara, G., Dahlgren, P., Dee, D., Diamantakis, M., Dragani, R., Flemming, J., Forbes, R., Fuentes, M., Geer, A., Haimberger, L., Healy, S., Hogan, R. J., Holm, E., Janiskova, M., Keeley, S., Laloyaux, P., Lopez, P., Lupu, C., Radnoti, G., de Rosnay, P., Rozum, I., Vamborg, F., Villaume, S., and Thepaut, J. N.: The ERA5 global reanalysis, Q. J. R. Meteorol. Soc., 146, 1999-2049, 2020.

Holton, J. R., Haynes, P. H., McIntyre, M. E., Douglass, A. R., Rood, R. B., and Pfister, L.: Stratosphere-troposphere exchange, Rev. Geophys., 33, 403-439, 1995.

Houweling, S., Baker, D., Basu, S., Boesch, H., Butz, A., Chevallier, F., Deng, F. Dlugokencky, E. J., Feng, L., Ganshin, A., Hasekamp, O., Jones, D., Maksyutov, S., Marshall, J., Oda, T., O’Dell, C. W., Oshchepkov, S., Palmer, P. I., Peylin, P., Poussi, Z., Reum, F., Takagi, H., Yoshida, Y., and Zhuravlev, R.: An intercomparison of inverse models for estimating sources and sinks of $\mathrm{CO}_{2}$ using GOSAT measurements, J. Geophys. Res. Atmos.,120, 5253-?5266, doi:10.1002/2014JD022962, 2014.,

Ishida, H., and T. Y. Nakajima, Development of an unbiased cloud detection algorithm for a spaceborne multispectral imager. J. Geophys. Res., 114, D07206, doi:10.1029/2008JD010710, 2009.

Ishida, H., Nakajima, T. Y., Yokota, T., Kikuchi, N., and Watanabe, H.: Investigation of GOSAT TANSO-CAI cloud screening ability through an intersatellite comparison, J. Appl. Meteo. Clim., 50, 1571-1586, DOI:10.1175/2011JAMC2672.1, 2011 b. 
IPCC: Climate Change 2013: The Physical Science Basis, Contribution of Working Group I to the Fifth Assessment Report of the Intergovernmental Panel on Climate Change, edited by Stocker, T. F., Qin, D., Plattner, G.-K., Tignor, M., Allen, S. K., Boschung, J., Nauels, A., Xia, Y., Bex, V., and Midgley, P. M., Cambridge University Press, Cambridge, United Kingdom and New York, USA, 1535 pp, doi:10.1017/CBO9781107415324, 2013.

IPCC: Climate Change 2021: The Physical Science Basis, Contribution of Working Group I to the Sixth Assessment Report of the Intergovernmental Panel on Climate Change, edited by Masson-Delmotte, V., Zhai, P., Pirani, A., Connors, S. L., Pan, C., Berger, S., Caud, N., Chen, Y., Goldfarb, L., Gomis, M. I., Huang, M., Leitzell, K., Lonnoy, E., Matthews, J. B. R., Maycock, T. K., Waterfield, T., Yeleki, O., Yu, R., and Zhou B., Cambridge University Press, Cambridge, United Kingdom and New York, USA, in press.

Jiang, X., Chahine, M. T., Olsen, E. T., Chen, L. L., and Yung, Y. L.: Interannual variability of mid-tropospheric $\mathrm{CO}_{2}$ from Atmospheric Infrared Sounder, Geophys. Res. Lett., 37, L13801, doi:10.1029/2010GL042823, 2010.

Kang, I.-S., Ho, C.-H. Lim, Y.-K., and Lau, K.-M.: Principal modes of climatological seasonal and intraseasonal variations of the Asian summer monsoon, Mon. Weather Rev., 127, 322-340, 1999.

Keeling, C. D., Chin, J. F. S., and Whorf, T. P.: Increased activity of northern vegetation inferred from atmospheric $\mathrm{CO}_{2}$ measurements, Nature, 382, 146-149, doi:10.1038/382146a0, 1996.

Kulawik, S. S., Jones, D. B. A., Nassar, R., Irion, F. W., Worden, J. R., Bowman, K. W., Machida, T., Matsueda, H., Sawa, Y., Biraud, S. C., Fischer, M. L., and Jacobson, A. R.: Characterization of Tropospheric Emission Spectrometer (TES) $\mathrm{CO}_{2}$ for carbon cycle science, Atmos. Chem. Phys., 10, 5601-?5623, doi:10.5194/acp-10-5601-2010, 2010.

Kuze, A., Suto, H., Shiomi, K., Urabe, T., Nakajima, M., Yoshida, J., Kawashima, T., Yamamoto, Y., Kataoka, F., and Buijs, H.: Level 1 algorithms for TANSO on GOSAT: processing and on-orbit calibrations, Atmos. Meas. Tech., 5, 2447-2467, doi:10.5194/amt-5-24472012, 2012.

Kuze, A., Suto, H., Shiomi, K., Kawatani, K., Tanaka, M., Ueda, Y., Deguchi, A., Yoshida, J., Yamamoto, Y., Kataoka, F., Taylor, T. E., and Buijs, H.: Update on GOSAT TANSO-FTS performance, operations, and data products after more than 6 years in space, Atmos. Meas. Tech., 9, 2445-2461, doi:10.5194/amt-9-2445-2016, 2016.

Langematz, U., Kunze, M., Kr" uger, K., Labitzke, K., and Roff, G. L.: Thermal and dynamical changes of the stratosphere since 1979 and their link to ozone and $\mathrm{CO}_{2}$ changes, J. Geophys. Res., 108(D1), 4027, doi:10.1029/2002JD002069, 2003.

Lindqvist, H., O’Dell, C. W., Basu, S., Boesch, H., Chevallier, F., Deutscher, N., Feng, L., Fisher, B., Hase, F., Inoue, M., Kivi, R., Morino, I., Palmer, P. I., Parker, R., Schneider, M., Sussmann, R., and Yoshida, Y.: Does GOSAT capture the true seasonal cycle of carbon dioxide? Atmos. Chem. Phys., 15,13023-13040, 2015.

Machida, T., Matsueda, H., Sawa, Y., Nakagawa, Y., Hirotani, K., Kondo, N., Goto, K., Ishikawa, K., Nakazawa, T., and Ogawa, T.: Worldwide measurements of atmospheric $\mathrm{CO}_{2}$ and other trace gas species using commercial airlines, J. Atmos. Ocean. Technol., 25, 1744-1754, 2008.

Machida, T., Tohjima, Y., Katsumata, K., and Mukai, H.: A new $\mathrm{CO}_{2}$ calibration scale based on gravimetric one-step dilution cylinders, in 15th WMO/IAEA Meeting of Experts on Carbon Dioxide, Other Greenhouse Gases, and Related Tracers Measurement Techniques, National Institute for Environmental Studies, GAW Rep., 194, 114-119, World Meteorological Organization, Geneva, Switzerland, 2011.

Madden, R., and Julian, P. R.: Observations of the 40-50-day tropical oscillation-a review, Mon. Weather Rev., 122, 814-837, https://doi.org/10.1175/1520-0493(1994)122\%3C0814:OOTDTO\%3E2.0.CO;2, 1994.

Maddy, E. S., Barnet, C. D., Goldberg, M., Sweeney, C., and Liu, X.: $\mathrm{CO}_{2}$ retrievals from the Atmospheric Infrared Sounder: Methodology and validation, J. Geophys. Res., 113, D11301, doi:10.1029/2007JD009402, 2008. 
Maksyutov, S., T. Oda, M. Saito, R. Janardanan, D. Belikov, J. W. Kaiser, R. Zhuravlev, A. Ganshin, V. K. Valsala, A. Andrews, L. Chmura, E. Dlugokencky, L, Haszpra, R. L. Langenfelds, T. Machida, T. Nakazawa, M. Ramonet, C. Sweeney, and D. Worthy, Technical note: A high-resolution inverse modelling technique for estimating surface $\mathrm{CO}_{2}$ fluxes based on the NIES-TM-FLEXPART coupled transport model and its adjoint, Atmos. Chem. Phys., 21, 1245-1266, doi:10.5194/acp-21-1245-2021, 2021.

Mote, P. W., Rosenlof, K. H., McIntyre, M. E., Carr, E. S., Gille, J. C., Holton, J. R., Kinnersley, J. S., Pumphrey, H. C., Russell III, J. M., and Waters, J. W.: An atmospheric tape recorder: The imprint of tropical tropopause temperatures on stratospheric water vapor, J. Geophys. Res. Atmos., 101, 3989-4006, doi:10.1029/95JD03422, 1996.

Nakazawa, T., Miyashita, K., Aoki, S., and Tanaka, M.: Temporal and spatial variations of upper troposphere and lower stratospheric carbon dioxide, Tellus, 43B, 106-117, 1991.

Nakazawa, T., Machida, T., Sugawara, S., Murayama, S., Morimoto, S., Hashida, G., Honda, H., and Itoh, T.: Measurements of the stratospheric carbon dioxide concentration over Japan using a balloon-borne cryogenic sampler, Geophys. Res. Lett., 22, 1229-1232, 1995.

Newell, R. E., and Gould-Stewart, S.: A stratospheric fountain? J. Atmos. Sci., 38, 2789-2796, 1981.

Niwa, Y., Tomita, H., Satoh, M., and Imasu, R.: A three-dimensional icosahedral grid advection scheme preserving monotonicity and consistency with continuity for atmospheric tracer transport, J. Meteorol. Soc. Jpn., 89, 255-268, 2011.

400 Niwa, Y., Machida, T., Sawa, Y., Matsueda, H., Schuck, T. J., Brenninkmeijer, C. A. M., Imasu, R., and Satoh, M.: Imposing strong constraints on tropical terrestrial $\mathrm{CO}_{2}$ fluxes using passenger aircraft based measurements, J. Geophys. Res., 117, D11303, doi:10.1029/2012JD017474, 2012.

Oort, A. H., and Yienger, J. J.: Observed interannual variability in the Hadley circulation and its connection to ENSO, J. Climate, 9, 27512767, https://doi.org/10.1175/1520-0442(1996)009<2751:Oivith>2.0.Co;2, 1996.

Park, M., Randel, W. J., Gettelman, A., Massie, S. T., and Jiang, J. H.: Transport above the Asian summer monsoon anticyclone inferred from Aura Microwave Limb Sounder tracers, J. Geophys. Res, 112, D16309, doi:10.1029/2006JD008294, 2007.

Park, M., Randel, W. J., Emmons, L. K., Bernath, P. F., Walker, K. A., and Boone, C. D.: Chemical isolation in the Asian monsoon anticyclone observed in Atmospheric Chemistry Experiment (ACE-FTS) data, Atmos. Chem. Phys., 8, 757-764, www.atmos-chemphys.net/8/757/2008/, 2008.

410 Park, M., Randel, W. J., Emmons, L. K., and Livesey, N. J.: Transport pathways of carbon monoxide in the Asian summer monsoon diagnosed from Model of Ozone and Related Tracers (MOZART), J. Geophys. Res., 114, D08303, doi:10.1029/2008JD010621, 2009.

Patra, P. K., T. Hajima, R. Saito, N. Chandra, Y. Yoshida, K. Ichii, M. Kawamiya, M. Kondo, A. Ito and D. Crisp, Evaluation of earth system model and atmospheric inversion using total column $\mathrm{CO}_{2}$ observations from GOSAT and OCO-2, Progress in Earth and Planetary Science, $8,25,2021$.

415 Ramaswamy, V., Schwarzkopf, M. D., Randel, W. J., Santer, B. D., Soden, B. J., and Stenchikov, G. L.: Anthropogenic and natural influences in the evolution of lower stratospheric cooling, Science, 311, 1138-1141, doi:10.1126/science.1122587, 2006.

Randel, W. J., and Park, M.: Deep convective influence on the Asian summer monsoon anticyclone and associated tracer variability observed with Atmospheric Infrared Sounder (AIRS), J. Geophys. Res. Atmos., 111, D12, 2006.

Saitoh, N., Imasu, R., Ota, Y., and Niwa, Y.: $\mathrm{CO}_{2}$ retrieval algorithm for the thermal infrared spectra of the Greenhouse Gases Observing Satellite: potential of retrieving $\mathrm{CO}_{2}$ vertical profile from high-resolution FTS sensor, J. Geophys. Res., 114, doi:10.1029/2008JD011500, 2009. 
Saitoh, N., Touno, M., Hayashida, S., Imasu, R., Siomi, K., Yokota, T, Yoshida, Y., Machida, T., Matsueda, H., and Sawa, Y.: Comparisons between XCH4 from GOSAT shortwave and thermal infrared spectra and aircraft CH4 measurements over Guam, SOLA, 8, doi:10.2151/sola.2012-036, 2012.

Saitoh, N., Kimoto, S., Sugimura, R., Imasu, R., Kawakami, S., Shiomi, K., Kuze, A., Machida, T., Sawa, Y., and Matsueda, H.: Algorithm update of GOSAT/TANSO-FTS TIR $\mathrm{CO}_{2}$ product (Version 1) and validation of the UTLS $\mathrm{CO}_{2}$ data using CONTRAIL measurements, Atmos. Meas. Tech., 9, 2119-2134, doi:10.5194/amt-9-2119-2016, 2016.

Saitoh, N., Kimoto, S., Sugimura, R., Imasu, R., Kawakami, S., Shiomi, K., Kuze, A., Niwa, Y., Machida, T., Sawa, Y., and Matsueda, H.: Bias assessment of lower and middle tropospheric $\mathrm{CO}_{2}$ concentrations of GOSAT/TANSO-FTS TIR Version 1 product, Atmos. Meas. Tech., 10, 3877-3892, doi:10.5194/amt-10-3877-2017, 2017.

Santee, M. L., Manney, G. L., Livesey, N. J., Schwartz, M. J., Neu, J. L., and Read, W. G.: A comprehensive overview of the climatological composition of the Asian summer monsoon anticyclone based on 10 years of Aura Microwave Limb Sounder measurements, J. Geophys. Res. Atmos., 122, 5491-5514, 2016.

Sawa, Y., Machida, T., and Matsueda, H.: Seasonal variations of $\mathrm{CO}_{2}$ near the tropopause observed by commercial aircraft, J. Geophys. Res. Atmos., 113, DOI, 10.1029/2008JD010568, 2008.

Sawa, Y., Machida, T., and Matsueda, H.: Aircraft observation of the seasonal variation in the transport of $\mathrm{CO}_{2}$ in the upper atmosphere, J. Geophys. Res. Atmos., 117, D05305, doi:10.1029/2011JD016933, 2012.

Sawa, Y., Machida, T., Matsueda, H., Niwa, Y., Tsuboi, K., Murayama, S., Morimoto, S., and Aoki, S.: Seasonal changes of $\mathrm{CO}_{2}$, $\mathrm{CH}_{4}$, $\mathrm{N}_{2} \mathrm{O}$, and $\mathrm{SF}_{6}$ in the upper troposphere/lower stratosphere over the Eurasian continent observed by commercial airliner, Geophys. Res. Lett., 42, 2001-2008, 2015.

Takagi, H., Saeki, T., Oda, T., Saito, M., Valsala, V., Belikov, D., Saito, R., Yoshida, Y., Morino, I., Uchino, O., Andres, R. J., Yokota, T., and Maksyutov, S.: On the benefit of GOSAT observations to the estimation of regional $\mathrm{CO}_{2}$ fluxes, SOLA, 7, 161-164, doi:10.2151/sola.2011$041,2011$.

Thoning, K. W., Tans, P. P., and Komhyr, W. D.: Atmospheric carbon dioxide at Mauna Loa Observatory 2. Analysis of the NOAA GMCC data, 1974-1985, J. Geophys. Res. Atmos., 94, D6, 8549-8565, JD094iD06p0854, 1989.

Umezawa, T., Matsueda, H., Sawa, Y., Niwa, Y., Machida, T., and Zhou, L. X.: Seasonal evaluation of tropospheric CO $\mathrm{C}_{2}$ over the Asia-Pacific region observed by the CONTRAIL commercial airliner measurements, Atmos. Chem. Phys., 18, 14851-14866, https://doi.org/10.5194/acp-18-14851-2018, 2018.

Wang, T., Zhang, Q., Kuilman, M., and Hannachi, A.: Response of stratospheric water vapour to $\mathrm{CO}_{2}$ doubling in WACCM, Clim. Dyn., 54, 4877-4889, https://doi.org/10.1007/s00382-020-05260-z, 2020.

WMO Greenhouse Gas Bulletin (GHG Bulletin) No. 8: The State of Greenhouse Gases in the Atmosphere Based on Global Observations through 2018, World Meteorological Organization (WMO), 2012.

WMO Greenhouse Gas Bulletin (GHG Bulletin) No. 9: The State of Greenhouse Gases in the Atmosphere Based on Global Observations through 2019, World Meteorological Organization (WMO), 2013.

WMO Greenhouse Gas Bulletin (GHG Bulletin) No. 10: The State of Greenhouse Gases in the Atmosphere Based on Global Observations through 2018, World Meteorological Organization (WMO), 2014.

WMO Greenhouse Gas Bulletin (GHG Bulletin) No. 15: The State of Greenhouse Gases in the Atmosphere Based on Global Observations through 2018, World Meteorological Organization (WMO), 2019. 
https://doi.org/10.5194/acp-2022-46

Preprint. Discussion started: 18 February 2022

(C) Author(s) 2022. CC BY 4.0 License.

(c) (P)
Atmospheric

Chemistry

and Physics

Discussions

WMO Greenhouse Gas Bulletin (GHG Bulletin) No. 16: The State of Greenhouse Gases in the Atmosphere Based on Global Observations through 2019, World Meteorological Organization (WMO), 2020.

WMO Greenhouse Gas Bulletin (GHG Bulletin) No. 17: The State of Greenhouse Gases in the Atmosphere Based on Global Observations through 2020, World Meteorological Organization (WMO), 2021.

WMO WDCGG Data Summary No.44, GAW Data, Volume IV-Greenhouse and Related Gases, https://gaw.kishou.go.jp/static/publications/summary/sum44/sum44.pdf, 2020.

465 Ying, N., Ye, Q., and Xia, J. J.: Interannual and seasonal cycles of $\mathrm{CO}_{2}$ from GOSAT and AIRS, IOP Conference Series: Earth Environ. Sci., 237, doi:10.1088/1755-1315/237/2/022003, 2019.

Yokota, T., Yoshida, Y., Eguchi, N., Ota, Y., Tanaka, T., Watanabe, H., and Maksyutov, S.: Global concentrations of $\mathrm{CO}_{2}$ and $\mathrm{CH}_{4}$ retrieved from GOSAT: First preliminary results, SOLA, 5, 160-163, 2009.

Yoshida, Y., Ota, Y., Eguchi, N., Kikuchi, N., Nobuta, K., Tran, H., Morino, I., and Yokota, T.: Retrieval algorithm for $\mathrm{CO}_{2}$ and $\mathrm{CH}_{4}$ column abundances from short-wavelength infrared spectral observations by the Greenhouse Gases Observing Satellite, Atmos. Chem. Phys., 4 , 717-734, https://doi.org/10.5194/amt-4-717-2011, 2011.

Yoshida, Y., Kikuchi, N., Morino, I, Uchino, O., Oshchepkov, S., Bril, A., Saeki, T., and Yokota, T.: Improvement of the retrieval algorithm for GOSAT SWIR $\mathrm{XCO}_{2}$ and $\mathrm{XCH}_{4}$ and their validation using TCCON data, Atmos. Meas. Tech., 6, 1533-1547, 2013.

Yu, W., Dessler, A. E., Park, M., and Jensen, E. J.: Influence of convection on stratospheric water vapor in the North American monsoon region, Atmos. Chem. Phys., 20, 12153-12161, https://doi.org/10.5194/acp-20-12153-2020, 2020.

Yun, K. S., Timmermann, A., and Stuecker, M. F.: Synchronized spatial shifts of Hadley and Walker circulations, Earth Syst. Dyn., 12, 121-132, 10.5194/esd-12-121-2021, 2021.

Xiong, X., S. Houweling, J. Wei, E. Maddy, F. Sun, and C. Barnet, Methane plume over south Asia during the monsoon season: satellite observation and model simulation, Atmospheric Chemistry and Physics, 9, 783-794, 2009. https://doi.org/10.5194/acp-9-783-2009 


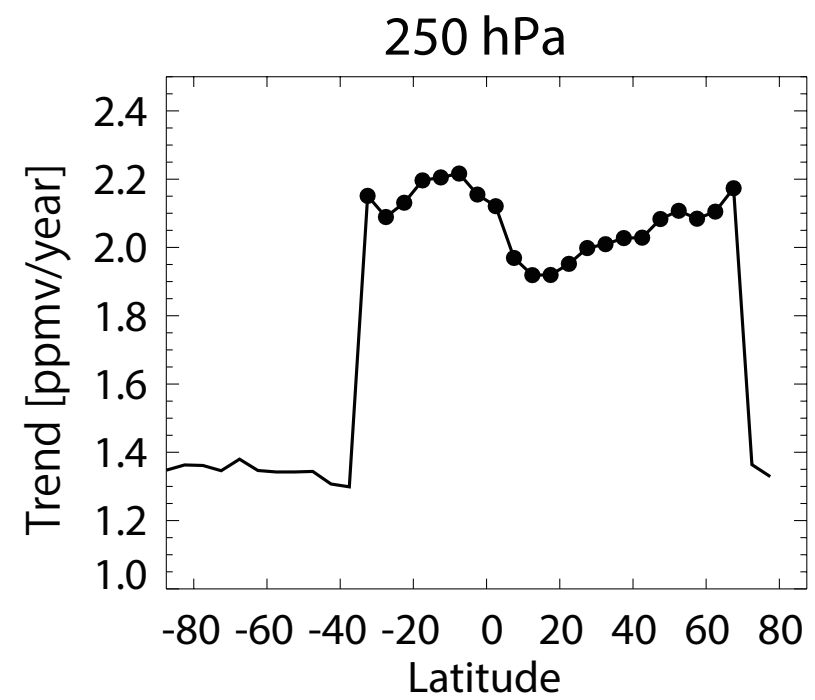

Figure 1. Latitudinal distribution of the trend of the $\mathrm{CO}_{2}$ mixing ratio at $250 \mathrm{hPa}$ from January 2010 to December 2013 . The dotted points indicate the latitude where the bias correction was applied $\left(30^{\circ} \mathrm{S}-70^{\circ} \mathrm{N}\right)$.

(a)
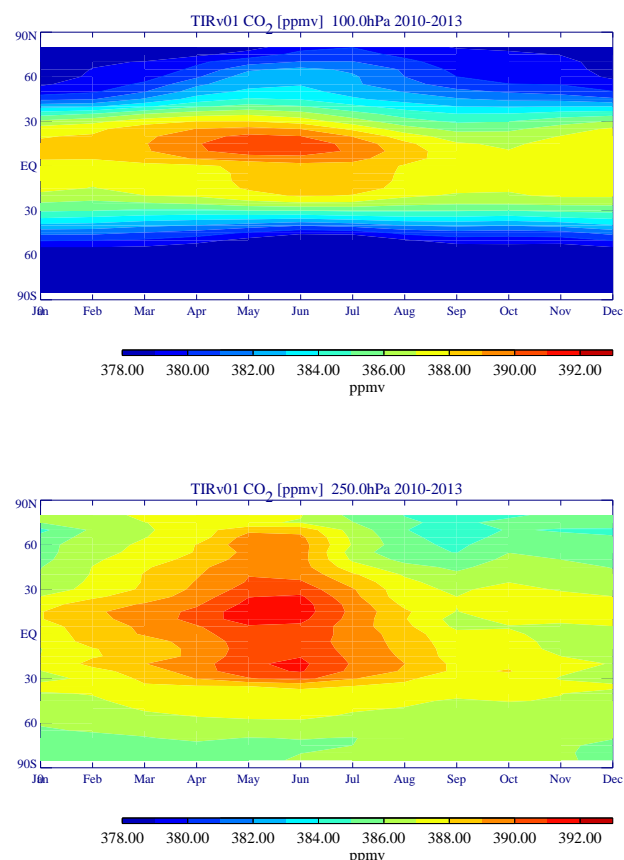
$\mathrm{ppm}$ (b)

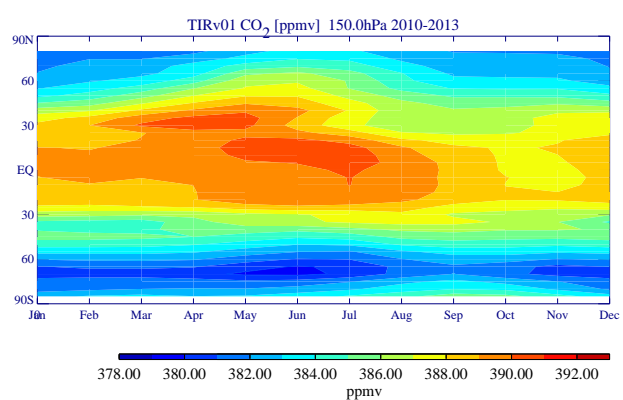

TIRv01 $\mathrm{CO}_{2}$ [Ppmv] 500.0hPa 2010-2013

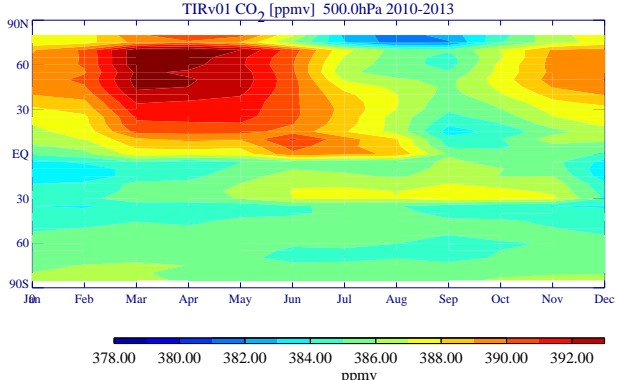

(d)

(c)

Figure 2. Time and latitude section of $\mathrm{CO}_{2}$ mixing ratios averaged over four years from January 2010 to December 2013 at (a) $100 \mathrm{hPa}$, (b) $150 \mathrm{hPa}$, (c) $250 \mathrm{hPa}$, and (d) $500 \mathrm{hPa}$. 
(a) Jan

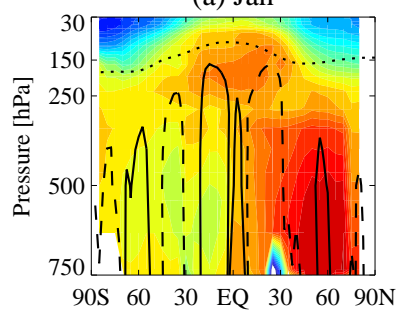

(e) May

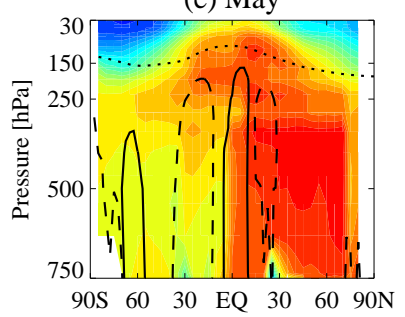

(i) Sep

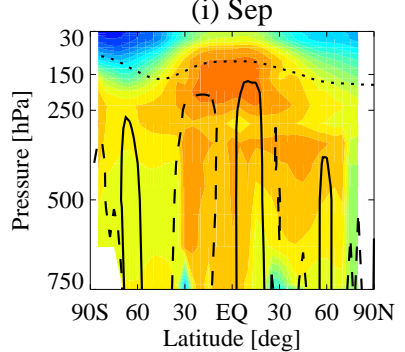

(b) Feb

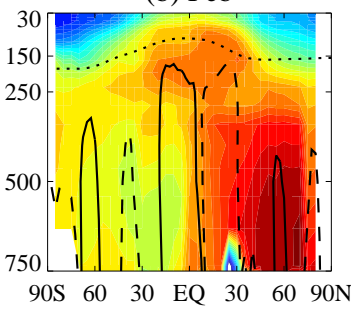

(f) Jun

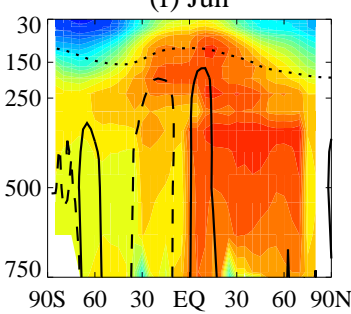

(j) Oct

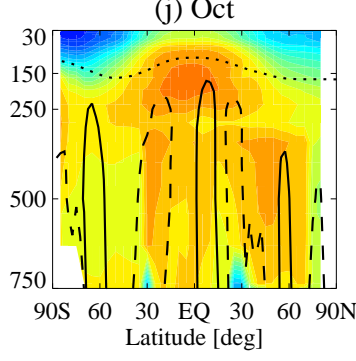

(c) Mar

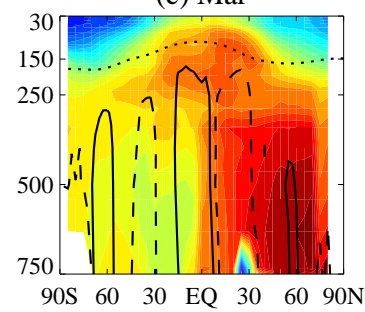

(g) Jul

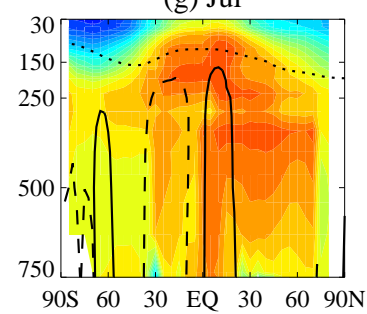

(k) Nov

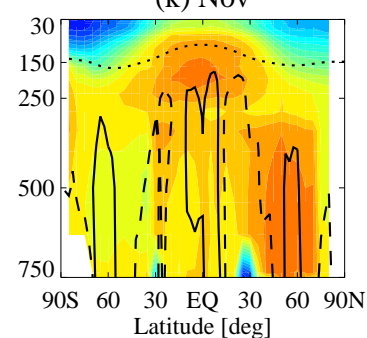

(d) Apr

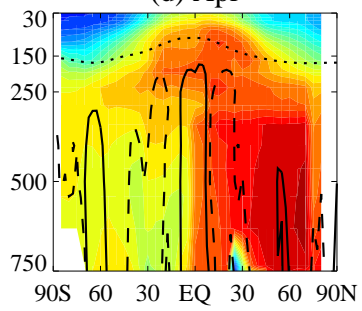

(h) Aug

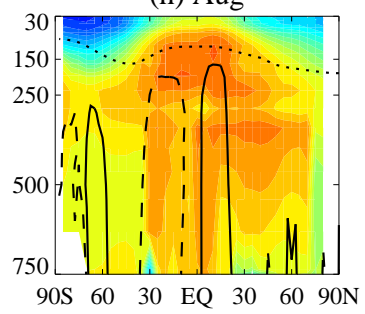

(1) Dec

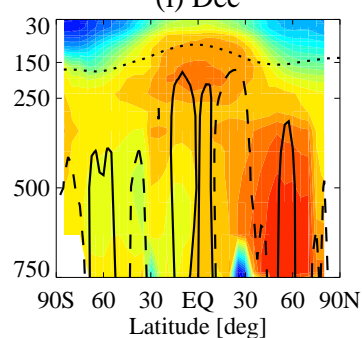

Figure 3. Latitude-pressure section of $\mathrm{CO}_{2}$ mixing ratios averaged over four years from 2010 to 2013 for each month, with de-trending applied. Dotted contours show potential temperatures of $370 \mathrm{~K}$, and solid and dashed contours show negative and positive pressure vertical velocities ( -1.0 and $1.0 \mathrm{~Pa} / \mathrm{s})$, respectively. 
(a)

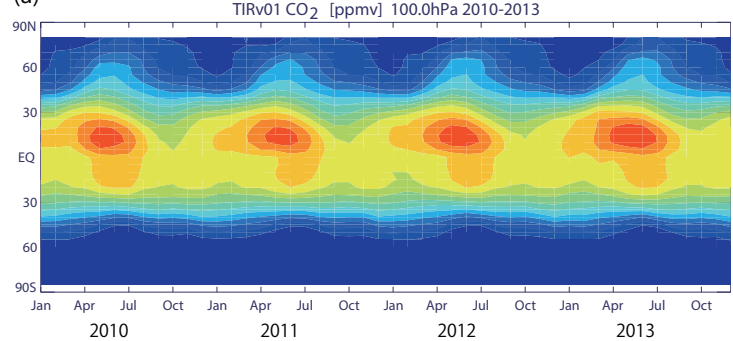

(c)

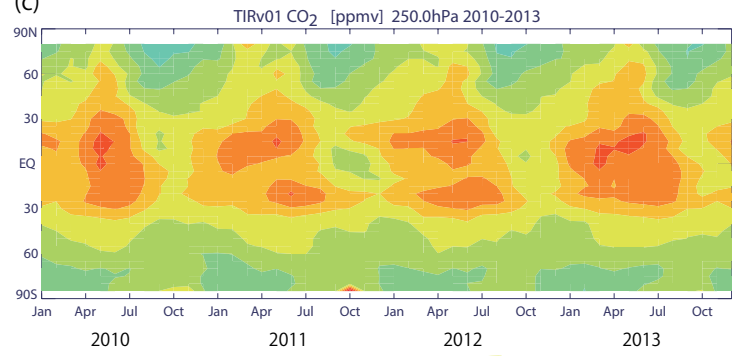

(b)

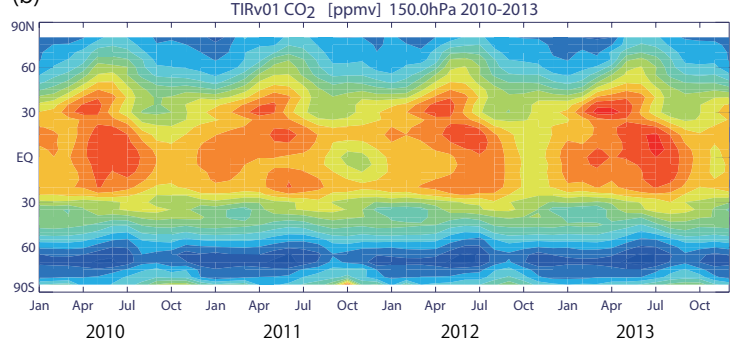

(d)

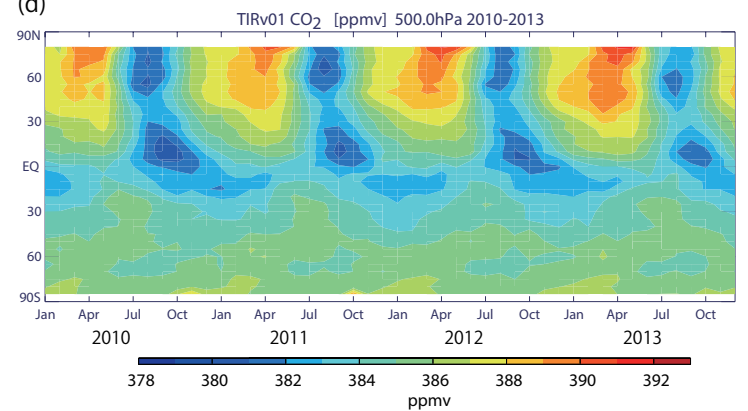

Figure 4. Time and latitude section of $\mathrm{CO}_{2}$ mixing ratios from January 2010 to December 2013, without trends at each latitude and pressure, for (a) $100 \mathrm{hPa}$, (b) $150 \mathrm{hPa}$, (c) $250 \mathrm{hPa}$, and (d) $500 \mathrm{hPa}$.

(a)

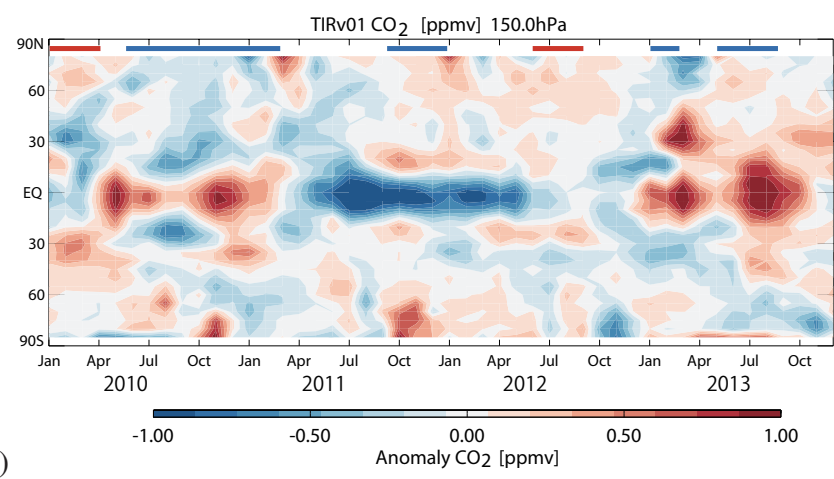

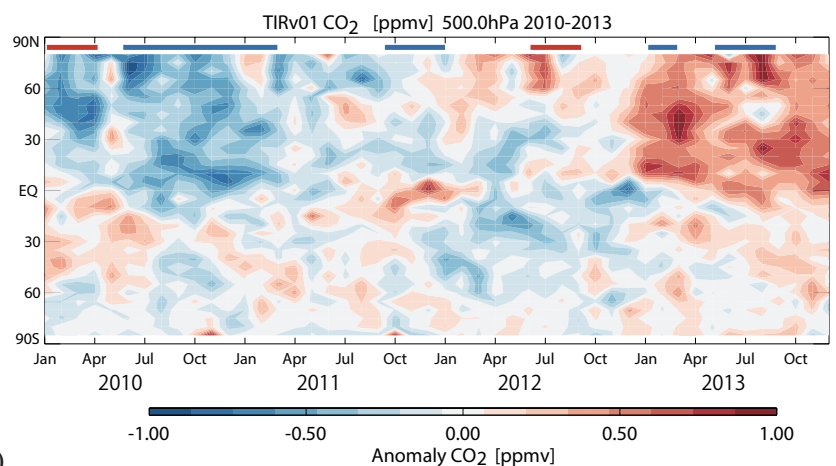

(b)

Figure 5. Same as Figure4, but for the anomaly from the monthly average. (a) $150 \mathrm{hPa}$ and (b) $500 \mathrm{hPa}$. The red (blue) horizontal lines at the top of panels show the sea surface temperature in Nino3 $\left(5^{\circ} \mathrm{N}-5^{\circ} \mathrm{S}, 150^{\circ} \mathrm{W}-190^{\circ} \mathrm{W}\right)$ higher(lower) than 0.5 degree $\mathrm{C}$ from the 30 -year average over there. 
https://doi.org/10.5194/acp-2022-46

Preprint. Discussion started: 18 February 2022

(c) Author(s) 2022. CC BY 4.0 License.

TIRv01 $\mathrm{CO}_{2}$ [ppmv] $0250 \mathrm{hPa}$ Longitude 60E to $120 \mathrm{E}$ D-N 2010

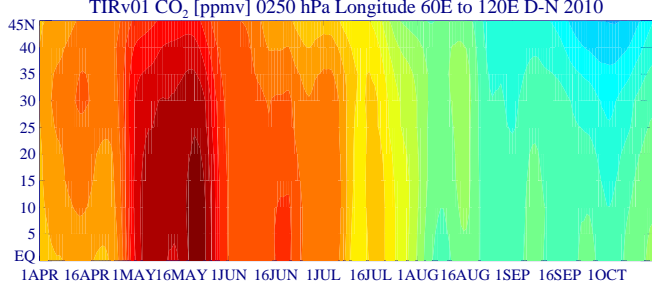

(a)

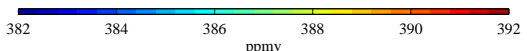

TIRv01 $\mathrm{CO}_{2}$ [ppmv] $0250 \mathrm{hPa}$ Longitude 60E to 120E D-N 2012

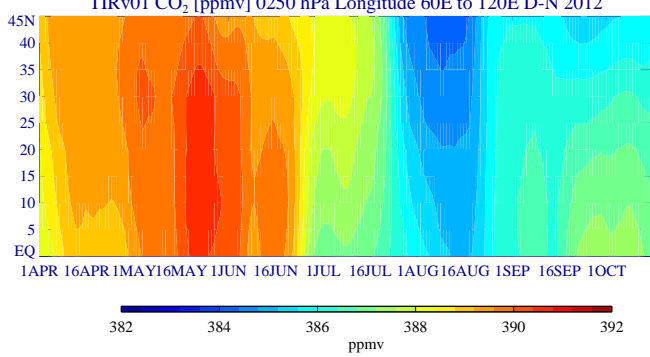

TIRv01 $\mathrm{CO}_{2}$ [ppmv] $0250 \mathrm{hPa}$ Longitude 60E to 120E D-N 2011

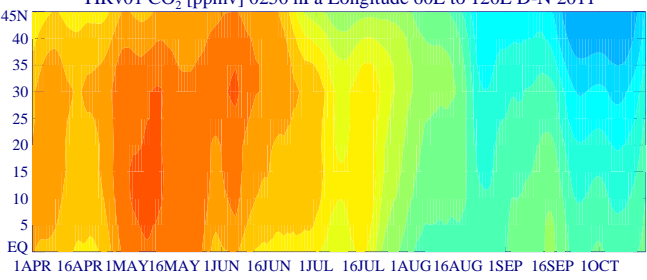

(b)

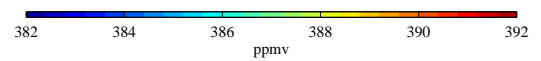

TIRv01 $\mathrm{CO}_{2}$ [ppmv] $0250 \mathrm{hPa}$ Longitude 60E to 120E D-N 2013

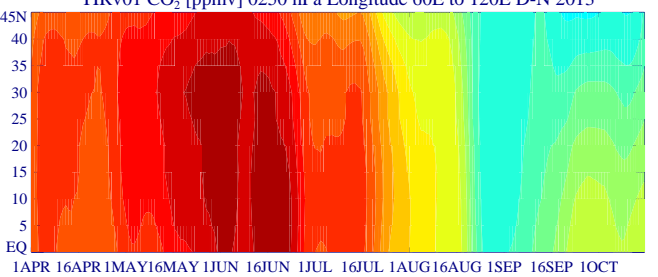

(d)

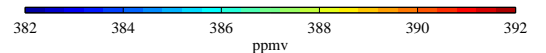

Figure 6. Time and latitude section of $\mathrm{CO}_{2}$ mixing ratios at $250 \mathrm{hPa}$ in each year averaged between $60^{\circ} \mathrm{E}$ and $120^{\circ} \mathrm{E}$ and shown as a 5 -day running mean without trends at each latitude and pressure. 
https://doi.org/10.5194/acp-2022-46

Preprint. Discussion started: 18 February 2022

(c) Author(s) 2022. CC BY 4.0 License.

(a) 16 Jun

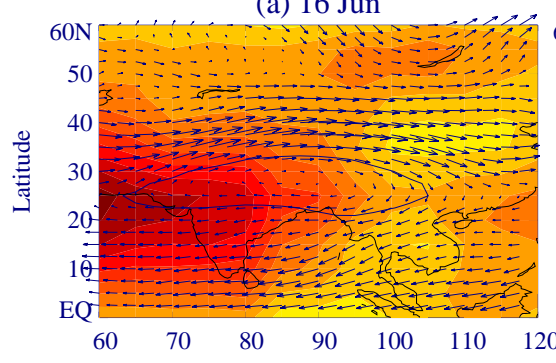

(d) 1 Aug

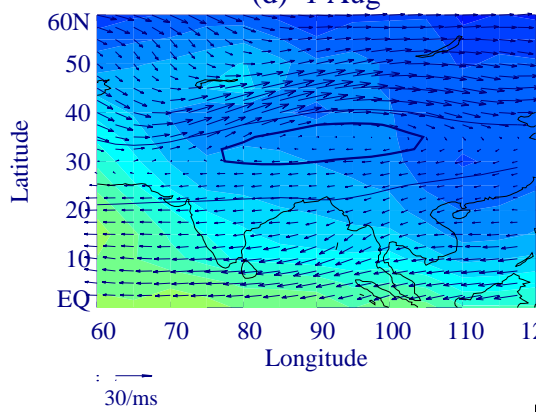

(b) $1 \mathrm{Jul}$

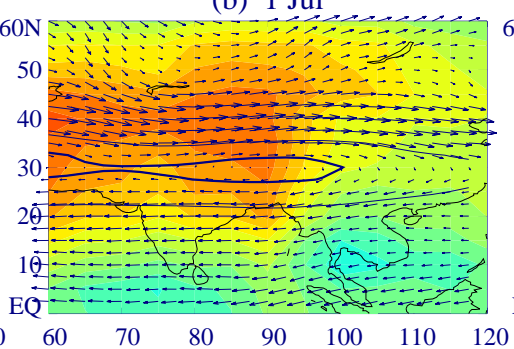

(e) $16 \mathrm{Aug}$
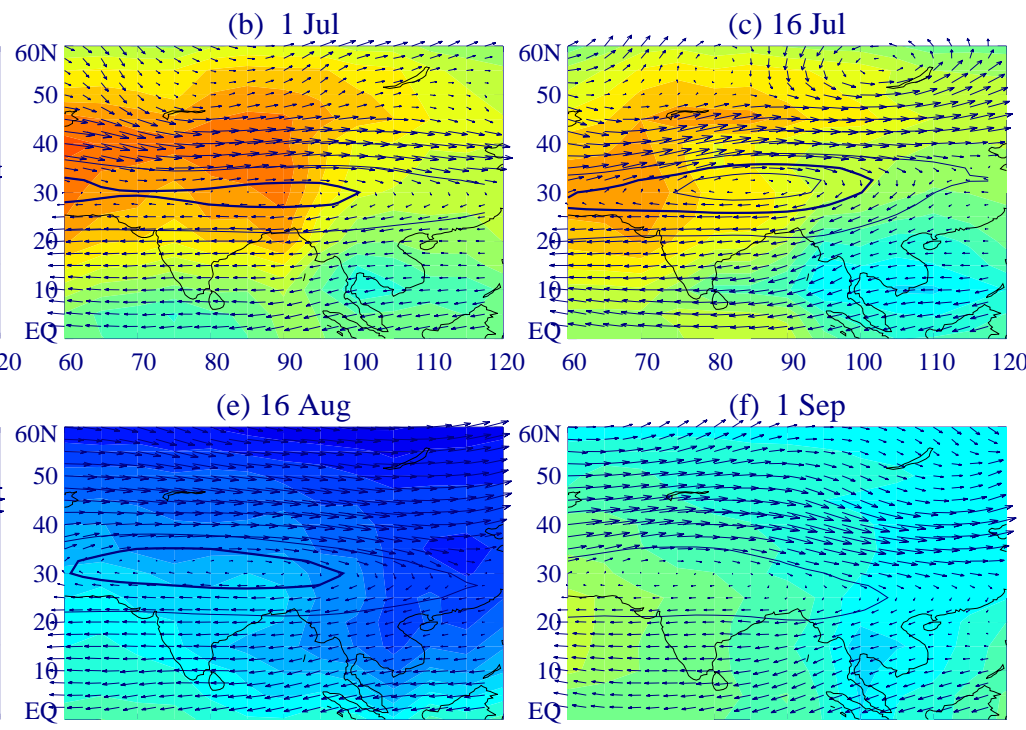

(f) $1 \mathrm{Sep}$
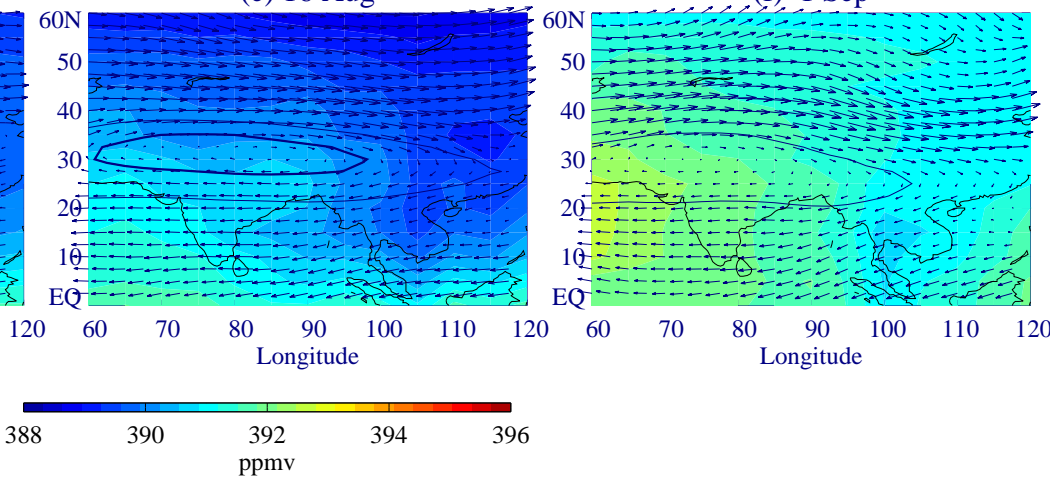

Figure 7. Map of $\mathrm{CO}_{2}$ mixing ratios at $250 \mathrm{hPa}$ as a 14-day average from (a) 16 June 2012, which shows the horizontal winds [m/s] (vectors) and geopotential height $\left[\mathrm{m}^{2} / \mathrm{s}^{2}\right]$ (contours). Contour lines represent 11000, 11040, and 11060 [m]. (b-f) The thick contour is 11040 [m]. The same as (a), but for the 14-day averages from 1, July, 16 July, 1 August, 16 August, and 1 September, respectively. 
https://doi.org/10.5194/acp-2022-46

Preprint. Discussion started: 18 February 2022

(c) Author(s) 2022. CC BY 4.0 License.

(c) (i)

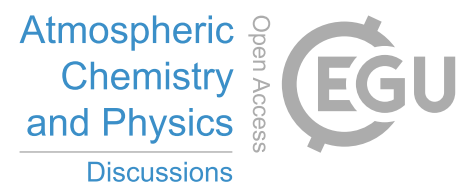

Table 1. The trend [ppmv year ${ }^{-1}$ ] (average, standard deviation, and minimum and maximum values) at each pressure level derived from GOSAT TANSO-FTS TIR data. The trend was calculated for the latitude range of $80^{\circ} \mathrm{S}$ to $80^{\circ} \mathrm{N}$ at 100 and $150 \mathrm{hPa}$ and $30^{\circ} \mathrm{S}$ to $70^{\circ} \mathrm{N}$ at 250 and $500 \mathrm{hPa}$, at $5^{\circ}$ intervals (January 2010 to December 2013).

\begin{tabular}{c|cccc}
\hline $\begin{array}{c}\text { Trend from } 2010 \text { to } 2013 \\
\left.\text { ppmv year }^{-1}\right]\end{array}$ & 100 & 150 & 250 & 500 \\
\hline Ave. & 2.02 & 1.82 & 2.08 & 1.87 \\
STD & 0.08 & 0.31 & 0.09 & 0.30 \\
Max. & 2.15 & 2.17 & 2.22 & 2.35 \\
Min. & 1.86 & 1.22 & 1.92 & 1.50 \\
\hline
\end{tabular}

